\title{
Gynandromorphs of New Zealand Austrosimulium spp. (Diptera: Simuliidae)
}

\author{
DOUGLAS A. CRAIG ${ }^{1} \&$ TREVOR K. CROSBY ${ }^{2}$ \\ ${ }^{1}$ Department of Biological Sciences, University of Alberta, Edmonton, T6G 2E9 Canada. E-mail: d.craig@ualberta.ca \\ ${ }^{2}$ Landcare Research Inc., 231 Morin Road, St Johns, Auckland 1142, New Zealand. E-mail: crosbyt@landcareresearch.co.nz
}

\begin{abstract}
Investigations in the 1970s of Leucocytozoon tawaki Fallis, Bisset \& Allison, a blood parasite of New Zealand's Fiordland Crested Penguins (Eudyptes pachyrhynchus Gray) - parasites normally transmitted by female simuliids - resulted in the trapping of some 20 thousand female Austrosimulium (Austrosimulium) adults, attracted to captive penguins. Three species were involved: Austrosimulium (A.) australense (Schiner), A. (A.) dumbletoni Crosby and A. (A.) ungulatum Tonnoir. Of those adults trapped, 24 were gynandromorphs; one other was obtained from elsewhere. Austrosimulium dumbletoni has only its female adult described; the two other species have all their stages known. Eight gynandromorphs of $A$. dumbletoni have been identified and elsewhere will be used formally to describe, for the first time, the male of this species. Here, synoptic descriptions of the gynandromorphs are provided.
\end{abstract}

Key words: Simuliidae, taxonomy, gynandromorphs, Austrosimulium, dumbletoni, ungulatum, australense, Leucocytozoon

\section{Introduction}

Gynandromorphs are of substantial interest, in part because they are rarely encountered, but in the main because of the unusual juxtaposition of male and female structures, in particular those of the genitalia. Such can provide information on homologies (Adler et al. 2004), particularly when alternate sides are of the other sex (Crosskey 1991).

There are two primary reasons why the gynandromorphs described here are of interest. First, with one exception, the specimens are from an intensive investigation of a bird blood parasite in New Zealand. Up until the early 1970s New Zealand's native avifauna was thought to be free of the genus of cosmopolitan blood parasite Leucocytozoon, which (with few exceptions) is transmitted by simuliids (black flies or sandflies) (Fallis et al. 1976). That changed in the mid-1970s when a moulting Fiordland Crested penguin (Eudyptes pachyrhynchus Gray) came ashore at Kaikoura (east central South Island)—well removed from the normal moulting grounds of this species (Warham 1974) in Fiordland, on the southwest coast of South Island. This penguin was positive for Leucocytozoon. Subsequently, in a major investigation in February 1975 at Jackson Bay, Westland (S43.972 ${ }^{\circ}$ E168.615 $)$, other Fiordland Crested penguins were also found to be positive (Fallis et al. 1976). Moulting penguins were caged and the simuliid adults attracted to the birds captured - then, some hundreds of the insects. Three species were implicated in transmitting the Leucocytozoon: Austrosimulium (Austrosimulium) ungulatum Tonnoir, A. (A.) australense (Schiner) and a new species with markedly large females. The Leucocytozoon, a new species, was given the specific epithet of tawaki by Fallis et al. (1976). The new species of simuliid, a member of the ungulatum group, was described by Crosby (1976) as Austrosimulium (Austrosimulium) dumbletoni, to honour L. J. Dumbleton for his earlier work on New Zealand Simuliidae, however, only the female of this species was described, and subsequently no other stage has been found. 
It was clear at the time that the stimulus attracting female simuliids to penguins was neither visual, since the birds were caged, nor pheromone-related, unlike that known for some other simuliids such as the North American Simulium annulus (formerly S. euryadminiculum) in which the females are attracted to uropygial gland secretions of the Common Loon (Gavia immer) (Fallis et al. 1976, Crosby 1988). Since the penguins were in enclosed cages, the attractant for the simuliid females was probably, as normal, exhaled carbon dioxide from the birds. We note, however, that while A. australense and A. ungulatum are well known to bite humans, A. dumbletoni does not, even though the females may be attracted in large numbers (DAC. pers obs). Exhaled carbon dioxide would then appear to be not the only stimulus needed for biting in this species.

Further investigation into L. tawaki, again using caged penguins, was done during the summers of 1977 and 1978. (Allison et al. 1978, Desser and Allison 1979, and label data in Table 1). Of 23,500 simuliid female adults collected, variably 75\% were A. ungulatum, 15-25\% A. dumbletoni and the remaining 5\%, A. australense. Twenty-four individuals could be classified as gynandromorphs or intersexes. Of these, eight are identifiable as A. dumbletoni, seven as A. australense and nine as A. ungulatum. One other A. australense gynandromorph specimen was obtained from further north on Westland, when attracted to the second author.

Second, only females of $A$. dumbletoni are known. Intense collecting by both authors in local streams and rivers around Jackson Bay, Westland, has failed to reveal earlier stages-in particular mature pupae from which the unknown male could be reared and described. So, the gynandromorphs of this species importantly allow description of male characters for the first time.

Use of gynandromorphs for taxonomic purposes has precedent. Smart (1945) noted that description of a gynandromorph by Puri (1933) helped with taxonomic difficulties regarding segregation of Simulium and Eusimulium.

Gynandromorphy, intersexes, and female behaviour performed by apparently fully male individuals, are not unknown in Austrosimulium. Crosby (1973) described a single gynandromorph of A. (A.) australense. Other examples in the Australian A. (Novaustrosimulium) bancrofti have been described by Hunter and Moorehouse (1976), associated with mermithid parasitism.

\section{Material and methods}

Definition of gynandromorphy.

Definitions of gynandromorphy are legion. Heming (2003), amongst others, defines a 'gynandromorph' as an individual in which some parts of the body are male and some female, with the boundary between such parts abrupt, whereas an 'intersex' is an individual with the junction between male and female parts diffuse. Adler et al. (2004), for Simuliidae, used the term 'sexual mosaics', with two categories, 'gynandromorph' where the cells are a mixture of male and female and structurally the parts are distributed regularly, or at random, and 'intersexes' having cells of a single genotype, and tending to be bilaterally symmetrical with anterior-posterior trends towards the opposite sex.

The term 'feminization' is commonly used for males parasitized by mermithid nematodes and showing female characteristics including behaviour (Hunter and Moorehouse, 1976). Parasitic nematodes are known (Poinar 1990) for only one simuliid in New Zealand, A. multicorne, but there is no mention of abnormal arrangement of adult structures. So far, Poinar's example is unique.

Since many of the definitions above are not mutually exclusive, because the specimens treated here show variously all conditions, and since we have no information on underlying cause, we use the term gynandromorph in its original sense (OED. Greek, gyne $=$ a female, andros $=$ a male, morphe $=$ form $)$, usage in keeping with that of Sublette and Martin (1995), for chironomids and from similar reasoning. 


\section{Specimens}

The adults had been stored in 70\% ethanol since their collection in 1977, 1978 and 1984 and although in almost pristine condition, are slightly bleached. Specimens were photographed before dissection using a Nikon, CoolPix $4500^{\circledR}$ digital camera, a Wild M20 compound microscope and Helicon Focus ${ }^{\circledR}$ software. Final images in the plates were manipulated in Photoshop Creative Suite ${ }^{\circledR}$.

After being photographed, the head was cleared of soft tissue in $10 \%$ potassium hydroxide (KOH). Similarly, the abdomen was removed, a sample of its internal contents mounted in polyvinyl lactophenol (PVLP) on a glass slide and the remaining posterior portion cleared in $\mathrm{KOH}$. After being photographed in glycerine, the genitalia were placed in a $\mathrm{BEEM}^{\circledast}$ capsule along with the remainder of the specimen. Claws from male and female legs were mounted on slides in PVLP and photographed at 500X under oil.

In simuliids, identification of male and female structures other than genitalia is sometimes uncertain. With few exceptions, however, male eyes have larger upper ommatidia and these meet on the dorsal midline (holoptic), whereas, female eyes have smaller ommatidia and are separated by the frons (dichoptic). In Austrosimulium spp. and elsewhere, the male thorax is typically highly domed, the female's less so. The pleural mesepimeral tuft, ventral of the wing base is more highly developed in males, as is the basal scale (the 1st abdominal tergite) - both with longer hairs. Male and female antennae differ subtly, those of the male being more tapered (Crosby 1974). The 3rd segment of the palpus in males is shorter and proximally expanded to accommodate the sensory vesicle, or Lutz's organ, while in females it is more elongate (Crosby 1974, DAC pers obs). Male and female pretarsal claws are distinct: the male possessing a dorsal grappling comb, used during copulation for engaging the female vestiture (Craig and Craig 1986).

All material is deposited in the New Zealand Arthropod Collection (NZAC) held in trust by Landcare Research Inc., St. Johns, Auckland, New Zealand. The microscope slides containing legs and head structures (antennae and mouthparts) from these specimens are in the Dumbleton Slide Collection. Other material is in separately numbered (Table 2) BEEM capsules within shell vials in the Alcohol Collection and labelled 'Gynandromorphs', and separated by species. Field-label data for the specimens is given in Table 1.

\section{Identification to species}

With males known for A. ungulatum and A. australense, (Tonnoir 1925, Dumbleton 1973), we had no difficulty confirming that the gynandromorph male genitalic structures and other diagnostic features, when expressed in full, hold true to structures of known exemplars.

Identification of gynandromorphs to species was confirmed, however, in part, by using female structures. For example, in those gynandromorphs thought to be of A. dumbletoni, the female claws possess a large basal thumb-like structure with a proximal notch (Fig. 3). Further, the 3rd segment of the female maxillary palpus is elongate and tubular (Fig. 5). For males the genitalia possess a ventral plate with a well-developed, hairy, median keel and the gonocoxites a shallow anteromedian notch (Fig. 6). Further, the gonostyli are smoothly tapered with two apical teeth. These character states firmly place the specimens in the ungulatum group (A. ungulatum, A. dumbletoni, A. vexans, A. campbellense, A. unicorne, A. bicorne) of Austrosimulium (Austrosimulium) (Dumbleton 1973). Since A. vexans and A. campbellense are known only from the Auckland Islands and Campbell Island in the sub-Antarctic, and A. unicorne and A. bicorne are high altitude species of limited distribution in the Southern Alps, final identification was mainly to ensure the gynandromorphs were not $A$. ungulatum.

Females of A. dumbletoni, are the largest known simuliid in New Zealand and the seven gynandromorphs assumed to be of that species were in the upper end of that species' size range (Crosby 1976), whereas $A$. ungulatum is markedly smaller. Further, the anterior veins of the wing are noticeably well developed and the wing blade is dusky (Fig. 1) - in agreement with those of females of A. dumbletoni. Gynandromorph antennae are of mixed provenance, with some being untapered as in females of A. dumbletoni, with others finely tapered, as in known males of the ungulatum group. Further the female antennae are evenly coloured as in $A$. 
dumbletoni, whereas in A. ungulatum, the 3rd article has a pale base-diagnostic for that species. Thus, eight of the 25 gynandromorphs are specimens of A. dumbletoni.

We provide below synoptic comments on the gynandromorphs, including a listing of character states (Table 2). One specimen is considered in detail and two others less so. More formal description of the male of A. dumbletoni, in particular that of the genitalia, will be given later (with caveats regarding the gynandromorphy), in a taxonomic revision of New Zealand Simuliidae.

TABLE 1. Label data for Austrosimulium gynandromorphs deposited in the New Zealand Arthropod Collection, Landcare Research Inc., St. Johns, Auckland, New Zealand. WD = Westland.

\begin{tabular}{|c|c|c|c|c|}
\hline \multicolumn{2}{|c|}{ Specimen } & Host & Time & Collector \\
\hline \multicolumn{5}{|l|}{ No. } \\
\hline \multicolumn{5}{|c|}{ A. dumbletoni } \\
\hline$\# 1 . \quad 1$ & NZ, WD, Jackson Bay, & Penguin 5, & 1900-2200h, & 12 Feb. 1977, T. K. Crosby. \\
\hline$\# 2$. & NZ, WD, Jackson Bay, & Penguin 4, & 2200-0800h, & 14 Feb. 1977, T. K. Crosby. \\
\hline & NZ, WD, Jackson Bay, & Penguin 2, & 1700-2200h, & 07 Feb. 1978,F. R. Allison. \\
\hline$\# 4,5$. & NZ, WD, Jackson Bay, & Penguin 4 , & 1900-2200h, & 11 Feb. 1977, T. K. Crosby. \\
\hline & NZ, WD, Jackson Bay, & Penguin 5, & 0700-1000h, & 10 Feb. 1977, T. K. Crosby. \\
\hline & NZ, WD, Jackson Bay, & Penguin 7 , & 1000-1900h, & 13 Feb. 1977, T. K. Crosby. \\
\hline$\# 8$. & NZ, WD, Jackson Bay, & Penguin 4 , & 0400-0700h, & 10 Feb. 1977, T. K. Crosby. \\
\hline \multicolumn{5}{|c|}{ A. australense } \\
\hline$\# 1,3$. 1 & NZ, WD, Jackson Bay, & Penguin 9, & 2200-1000h, & 12 Feb. 1977. T. K. Crosby. \\
\hline & NZ, WD, Jackson Bay, & Penguin 4 , & 1000-1900h, & 13 Feb. 1977. T. K. Crosby. \\
\hline & NZ, WD, Westport, & Attracted & & \\
\hline & Nine Mile Rd end. & to human & - & 01 Jun. 1984.T. K. Crosby. \\
\hline$\# 5,6,7$. 1 & NZ, WD, Jackson Bay, & Penguin 4, & 0700-1000h, & 10 Feb. 1977.T. K. Crosby. \\
\hline$\# 8 . \quad 1$ & NZ, WD, Jackson Bay, & Penguin 4, & 0800-1000h, & 13 Feb. 1977.T. K. Crosby \\
\hline \multicolumn{5}{|c|}{ A. ungulatum } \\
\hline$\# 1,2 . \quad 1$ & NZ, WD, Jackson Bay, & Penguin 7, & 1000-1900h, & 13 Feb. 1977. T. K. Crosby. \\
\hline & NZ, WD, Jackson Bay, & Penguin 6 , & 1900-2200h, & 10 Feb. 1977. T. K. Crosby. \\
\hline$\# 4,5$. & NZ, WD, Jackson Bay, & Penguin 4, & 0700-1000h, & 10 Feb. 1977. T. K. Crosby. \\
\hline & NZ, WD, Jackson Bay, & Penguin 8 , & 2200-1000h, & 12 Feb. 1977. T. K. Crosby. \\
\hline & NZ, WD, Jackson Bay, & Penguin 5, & 0700-1000h, & 10 Feb. 1977. T. K. Crosby. \\
\hline & NZ, WD, Jackson Bay, & Penguin 7 , & 2000-1000h, & 12 Feb. 1977. T. K. Crosby. \\
\hline & NZ, WD, Jackson Bay, & Penguin 7, & 1900-2200h, & 12 Feb. 1977. T. K. Crosby. \\
\hline
\end{tabular}

\section{Observations}

Austrosimulium dumbletoni Crosby, 1976.

Of the eight specimens, only one (\#3) has both fully expressed male eyes with large ommatidia, but they are dichoptic, a female characteristic. One (\#2) possesses a partially developed male eye on the left. One (\#4) is essentially fully male on the left side of the head. Four (\#1, 5, 6, 7) have complete female heads. Four (\#2, $3,6,7$ ) have antennae that are both female; the remaining specimens have male and female antennae. All specimens have fully developed female mouthparts, by which we mean substantial labrum and labium, and well developed mandibles and lacinae (e.g. Fig. 8). However, that mandible has teeth on the aboral surface at the apex - a condition not associated with Austrosimulium females. Two (\#3, 4), however, have male maxillary palpi (Fig. 8). Two $(\# 1,6)$ have only one male maxillary palpus, the other female. Five (\#2-6) have a fully domed male thorax, while two $(\# 1,7)$ are mainly female (Fig. 1). One specimen each possesses only 
male claws (\#2) or only female claws (\#7-see below) on the legs, the remaining six have mixtures of either male or female claws on each leg (e.g., Figs. 2,3$)$. Three specimens $(\# 4,6,8)$ have fully expressed male genitalia with little if any indication of abnormality. One (\#2), while with fully male genitalia, has slight indication of female structures (genital fork?) anteriorly to that. One (\#1) (Fig. 1), while with fully male genitalia, possessed a female-like 8th sternite and a spermatheca (Fig. 6). Two (\#5, 7) are fully female with minor abnormalities to the genitalia. Specimen \#7 may not be a gynandromorph, since it merely has some minor asymmetry of its female genitalia.

Of the most interest is Specimen \#1, that at first appears to be a blood-fed female and possesses a fully developed female head with a complete set of apparently functional mouthparts, but with full male genitalia (Fig. 1). Its combination of features is noted above. Further to this though, its legs are of mixed provenance with the forelegs both female (Fig. 2), and the mid legs female on the right and male on the left side. Both hind legs are male (Fig. 3). Male claws in Simuliidae have a grappling comb on the dorsal surface for engaging the female vestiture during copulation (Craig and Craig 1986). The abdomen is a mosaic of both male and female parts, and the tergites (e.g., Fig. 9) span the full width of the segment as is normal for Austrosimulium (Dumbleton 1972) males. Each tergite, however, has portions with female vestiture. The first abdominal segment, or basal scale, possesses long black hairs, typical of simuliid males (Crosskey 1991) on the right side, as in Figure 9. The male genitalia are unremarkable, except for a minor amount of asymmetry to the ring-like ninth sternite (Fig. 6). Initial examination indicated a certain amount of malformation (Figs. 1) of the 8th sternite immediately anterior to the gonocoxites.

The swollen anterior portion of the abdomen was not full of bird blood as had been initially surmised, but rather by a large number (200-300+) of fully developed chorionated eggs (Fig. 4), plus an equally large number of small pre-vitellogenic oocytes (Heming pers com. 2008). Further, the insect has a well-developed sclerotized spermatheca (Fig. 6) of unremarkable form, but apparently lacking a duct. The deformed 8th sternite now could be interpreted more probably as part of the female genital fork. What appeared to be three openings, one encompassed by the genital fork and the other two immediately posterior of that are, at high magnification, not openings. This is in agreement with lack of a spermathecal duct.

\section{Austrosimulium australense (Schiner) 1868.}

Of the eight A. australense gynandromorphs, only one (\#6) has the left side of the head fully female, with the right side male (Table 2). Five others (\#1,2,3,5,7) express female characteristics on the right side of the head. Another (\#4) with fully male eyes on both sides is slightly dichoptic (Fig 10). One (\#8) has a fully female head in all respects. All antennae, with one exception (\#3), appear to be female. Mouthparts are always completely male (e.g., Fig 10), except for \#8. Four (\#3-6) have a fully expressed, domed male thorax. One \#1 has a fully female thorax, two $(\# 2,7)$ have largely male thoraxes. All, except two, have either male or female claws on each leg; the exceptions are \#1 with all female claws and \#8 with all male. Four $(\# 3,6,7,8)$ have essentially unmodified male genitalia.

Specimen \#3 possesses a spermatophore (Fig. 11), a sperm packet deposited by male simuliids (Davies 1965). This is firmly placed between the 7th and 8th sternites - definitive evidence that this individual had mated!

Two specimens $(\# 4,5)$ have mixtures of male and female genitalia similar to that of A. ungulatum (e.g., Fig 14); one of these (\#5) has a swollen abdomen that on dissection showed only undifferentiated yolk. One specimen \#1 only has fully expressed female genitalia.

\section{Austrosimulium ungulatum Tonnoir 1925.}

Of the nine specimens identified as A. ungulatum, one (\#5) lacks the head (Table 2). Of the remainder, four (\#1-4) have the left side of the head fully female, two $(\# 6,7)$ male and two $(\# 8,9)$ partially male. Three $(\# 1,2,8)$ have fully expressed male eyes on the right (Fig. 12), another (\#7) is partially male on that side. The 


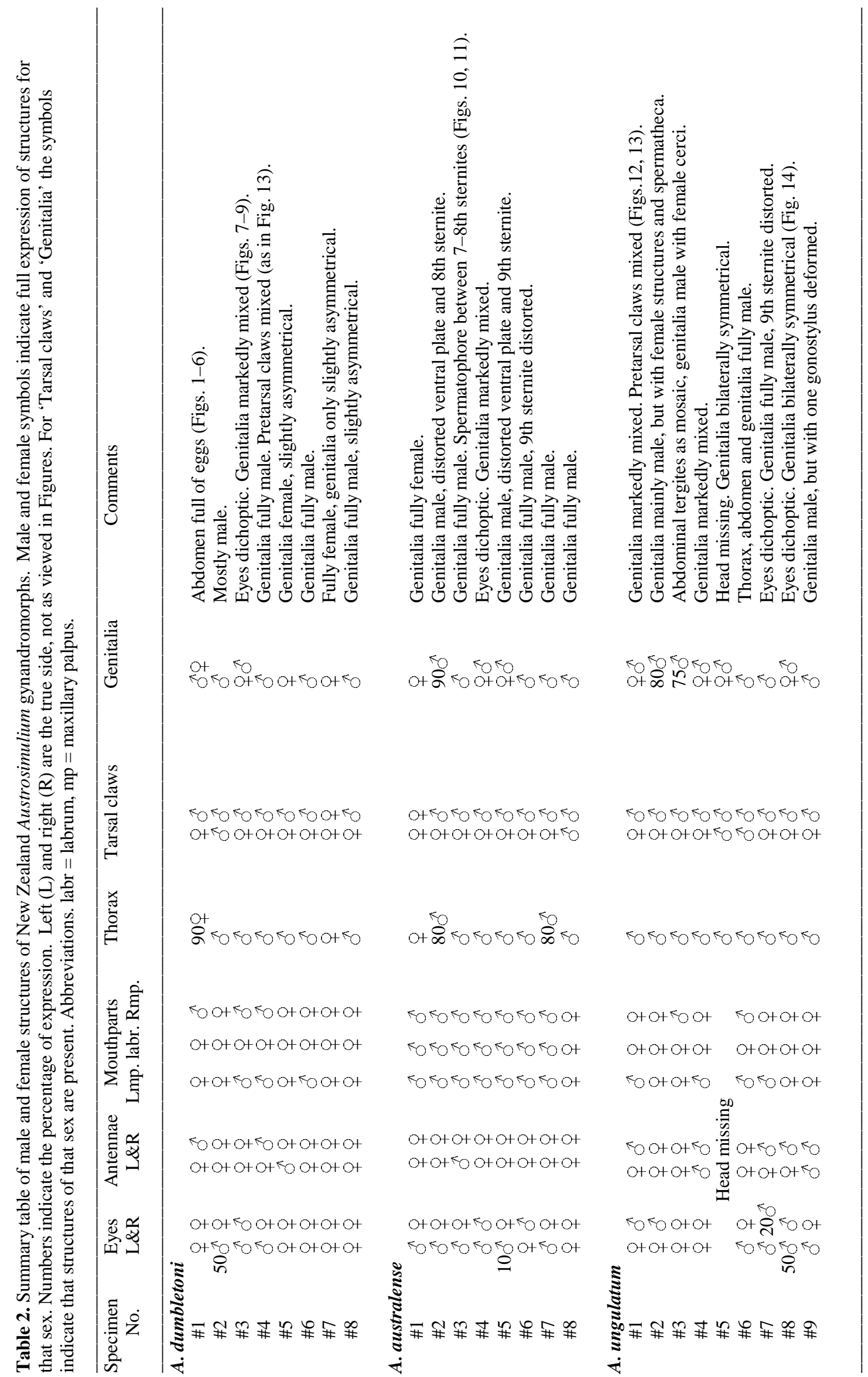



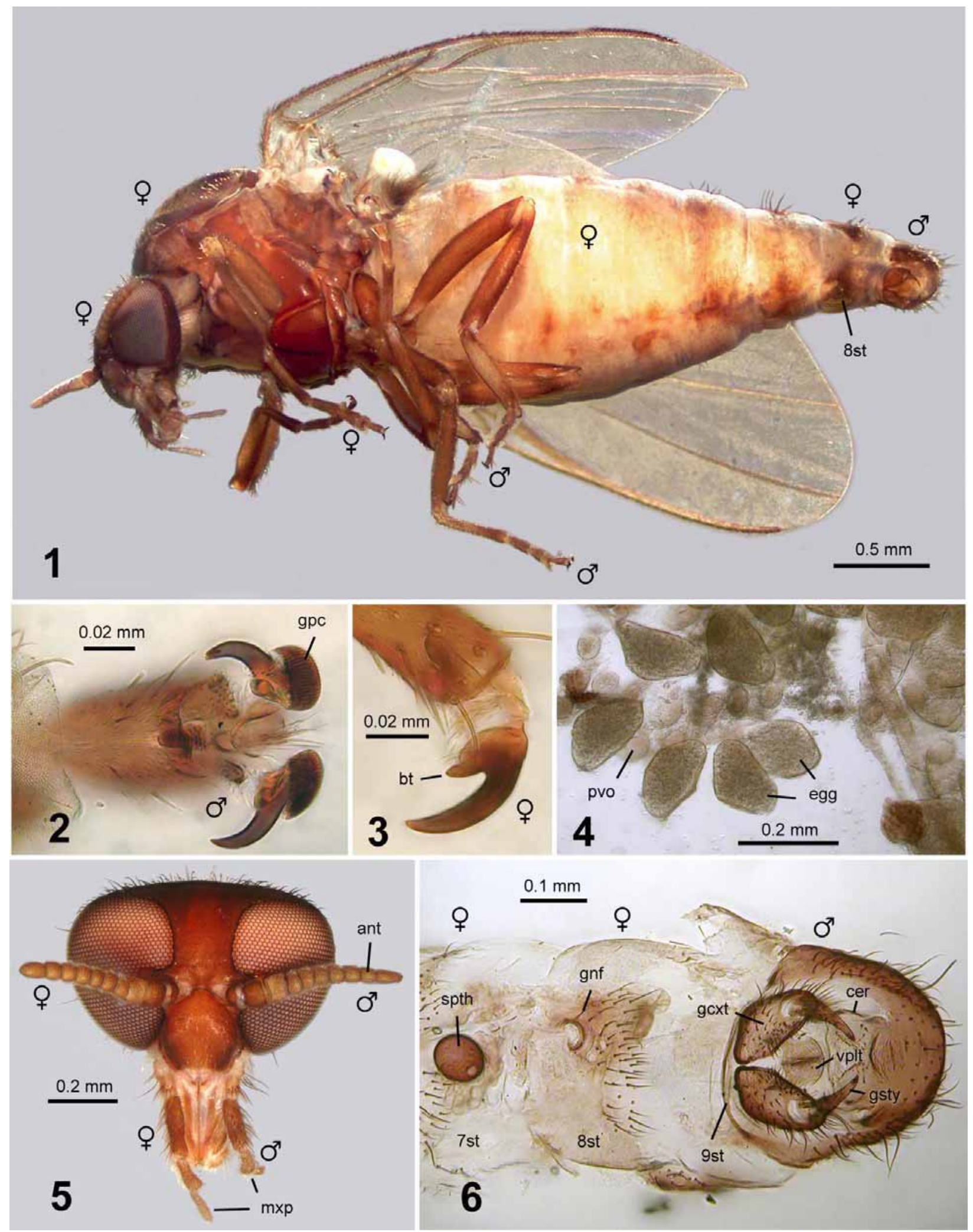

PLATE 1. Austrosimulium (Austrosimulium) dumbletoni gynandromorph (Specimen \#1). Fig. 1. Ventrolateral habitus. Note distended abdomen and distribution of male and female structures. Fig. 2. Male pretarsal claw. Note distinctive grappling comb on each claw. Fig. 3. Female claw. Note proximal thumb-like structure with basal notch. Fig. 4. Eggs and undeveloped pre-vitellogenic oocytes from distended abdomen. Fig 5. Frontal view of mainly female head. Fig. 6. Ventral view of posterior abdomen, cleared. Male genitalia to right, female spermatheca to left. The male $\left(0^{7}\right)$ and female ( $(9)$ symbols indicate structures of that sex. Abbreviations: ant—antenna; bt —basal tooth; cer—cercus; gcxt—gonocoxite; gnf—genital fork; gpc—grappling comb; gsty—gonostylus; mxp—maxillary palpus; pvo—pre-vitellogenic oocytes; spth— spermatheca; vplt— ventral plate; 7st—7th sternite; 8st—8th sternite; 9st—9th sternite. 
two specimens $(\# 7,8)$ having male eyes on both sides are dichoptic; however, both have only partially expressed male eyes on one side or the other. Two $(\# 3,4)$ have fully female heads and three specimens (\#1, 7 , 8) have both male and female antennae (e.g., Fig 12). All nine each have a fully expressed, domed, male thorax. Seven $(\# 1-4,7-9)$ have either male or female claws on the legs. Two $(\# 5,6)$ have only male claws. Specimen \#1 has, on one leg, both a male and a female claw (Fig. 13)! All specimens express some male genitalia, but only three $(\# 6,7,9)$ are fully so, though $\# 7$ has a distorted 8th sternite, and \#9 a deformed gonostylus. The remaining specimens show various mixtures of male and female genitalia, ranging from two $(\# 5,8)$ with essentially bilateral gynandromorphy (Fig. 14), to two $(\# 1,4)$ with essentially un-interpretable mixtures of genitalic structures.

\section{Discussion}

Simuliid gynandromorphs are rare. Ratios of occurrence, given by Crosskey (1991), range from 1 in 2,300 to 1 in 50,000. For our sample of Austrosimulium, collected from the penguins it is $c a$. 1 in 980 (24 in 23,500), the lowest ratio known to date for simuliids. Our sample is also large, being considerably more than the 18 specimens out of ca. 41,600 reported by Fredeen (1970) for Simulium vampirum (then as the S. arcticum complex), the previously lowest ratio reported (Crosskey 1991). Of all simuliids collected during the study involving Leucocytozoon tawaki, the least common was A. australense (5\%, Allison et al. 1978), but there were eight gynandromorphs - essentially equal in number of gynandromorphs from the far more numerous adults of the other two species. Austrosimulium australense would thus be a suitable species to investigate further.

Of prime interest here are the gynandromorphs of A. dumbletoni. These will allow almost full description of the previous unknown males, and as noted previously there is precedence for such use (Puri 1933, Smart 1945). We note, however, that this must be done with caution since expression of some character states is unusual, such as the double-toothed condition seen in the mandibles of specimen \#3 (Fig. 8), normally absent for Austrosimulium, but present in its sister taxon Paraustrosimulium (Dumbleton 1973).

Expression of gynandromorphy in these Austrosimulium adults raises questions. For example, the marked differences between A. australense adults and those of the other two species, where most of the A. australense gynandromorphs possess male, but dichoptic heads, and have male mouthparts. Gynandromorphs of the other two species generally possess female mouthparts (Table 2), even when the head is predominately male. Is this a species-specific response to a common causative agent, or is there a different cause of gynandromorphy in this species?

What might cause the gynandromorphy in these simuliids we studied? Most specimens have empty abdomens, free of mermithid parasites, well known to feminize structures and behaviour in nematocerous dipterans (Hunter and Moorehouse 1976, Crosskey 1991, Sharp and Hunter 2008). With only one example of a mermithid parasite known for New Zealand Austrosimulium (Poinar 1990), could other parasites be involved? Dumbleton (1973, p. 545) mentioned that A. unicorne larvae were parasitized by probable microsporidia. However, when later discussing parasitism in simuliids in general (p. 576-577), he made no mention of this. Batson (1983) commented similarly when reporting two new microsporidians in Austrosimulium larvae from the Taieri River system, South Island. He described one of them as representing a new genus and species Hirsutusporos austrosimulii, (Nosematidae), and the other a member of the Thelohaniidae. Both DAC and TKC (unpub. obs.) have observed microsporidia in Austrosimulium larvae, but it is not known if these were the ones described by Batson. In short, there is no known causative agent for gynandromorphy in New Zealand Austrosimulium. 


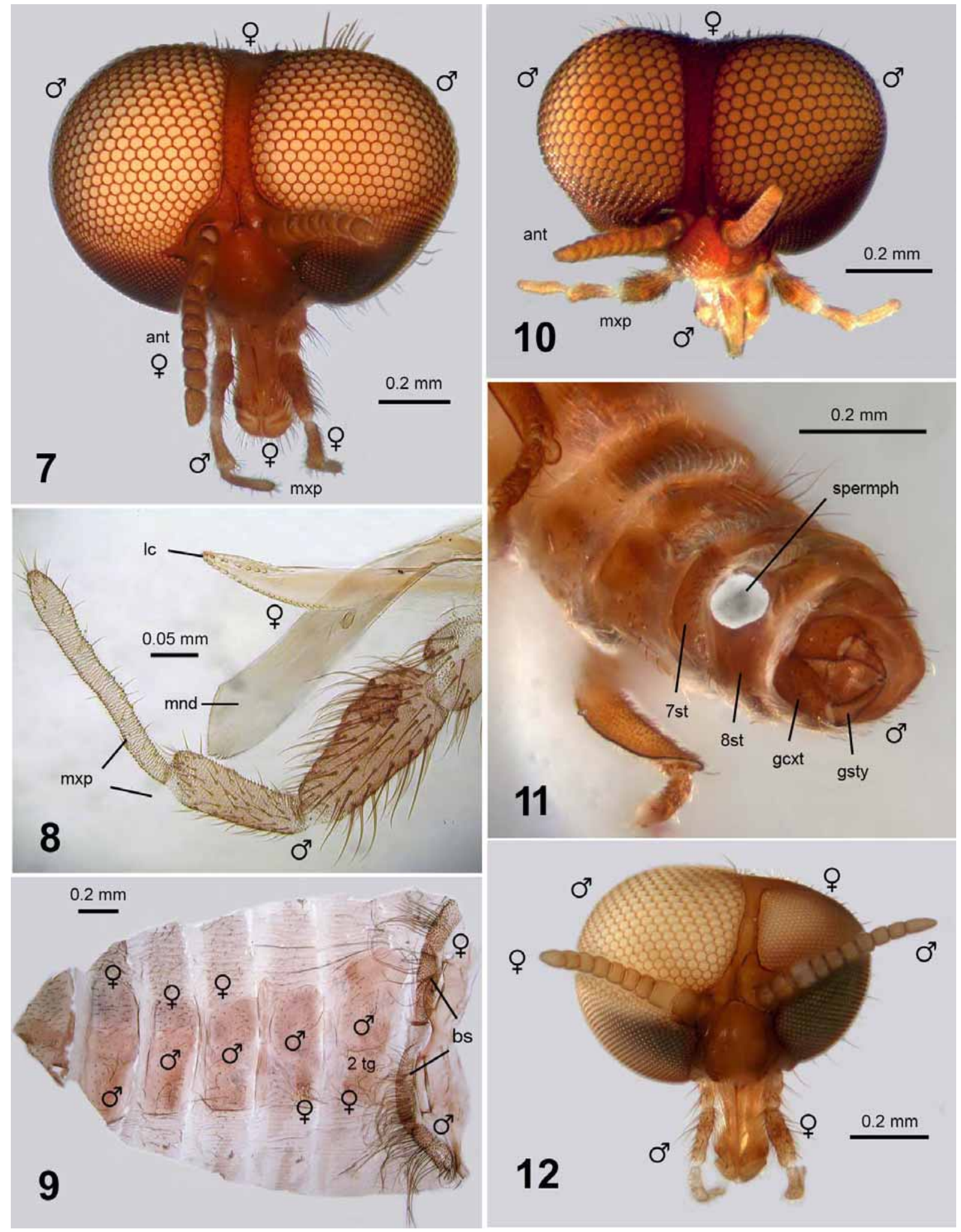

PLATE 2. Austrosimulium (Austrosimulium) dumbletoni gynandromorph (Specimen \#3). Fig. 7. Frontal view of head. Note dichoptic eyes.Fig. 8. Mouthparts. Left maxillary palpus, mandible and lacinia. Fig. 9. Abdominal tergites. Basal scale to right.

Austrosimulium (Austrosimulium) australense gynandromorph (Specimen \#3). Fig.10. Frontal view of head. Note dichoptic eyes. Fig. 11. Ventral view of posterior abdomen. Note spermatophore rammed between 7th and 8th sternite. Austrosimulium (Austrosimulium) ungulatum gynandromorph (Specimen \#1). Fig. 12. Frontal view of head. The male $\left(\sigma^{\top}\right)$ and female () symbols indicate structures of that sex. Abbreviations: ant- antenna; bs—basal scale; gcxt—gonocoxite; gsty—gonostylus; lc—lacinia; mnd—mandible; mxp—maxillary palpus; spermph—spermatophore; $7 \mathrm{st} — 7$ th sternite; 8st-8th sternite; 2tg-2nd tergite. 
Of the two specimens with engorged abdomens, that of A. dumbletoni (\#1), contained hundreds of fullydeveloped chorionated eggs (Fig. 4). Their subtriangular shape is a defining synapomorphy for Simuliidae and unmistakable (Adler et al. 2004). Other, smaller, spherical bodies are pre-vitellogenic oocytes with their surrounding follicle cells (Heming, pers com 2008). The other specimen, A. australense (\#5) has what appears to be undifferentiated yolk filling the abdomen, and there is no evidence, such as remnants of erythrocytes, that the material was a digested blood meal.

A gynandromorph with the abdomen engorged with fully developed eggs, raises additional questions. Had that specimen of A. dumbletoni blood fed? It certainly had mouthparts that would allow such (Fig. 8). While Dumbleton (1972) discussed in detail the gonotrophic cycles of simuliids, he provided no information for Austrosimulium spp., so nothing is known about reproduction in these insects. We can assume, however, with confidence, that transmission of Leucocytozoon tawaki dictates that a vector simuliid female feeds twice, at minimum, once to acquire the organism, the second to transmit it, with deposition of eggs developed from the first blood meal, in between. Hence, for Leucocytozoon-infected females of the three species attracted to and biting Fiordland Crested penguins, they must have taken at least one blood meal and already laid a batch of eggs after the meal, and would do so again - a common event in simuliids and other blood-feeding flies (Crosskey 1991). Time between blood meals is dictated by rate of digestion of the meal and that, in part, is determined by temperature. Fallis et al. (1976) and Allison, et al. (1978) indicated that at $c a \cdot 16^{\circ} \mathrm{C}$, digestion takes 10 days. How long eggs take to develop is unknown. Unrelated to this, Tonnoir (1925) reported eggs taking 14 days to embryonate and hatch. Downes (1958) noted that, for most species of simuliids, it is assumed a blood meal is necessary for full ovarian development; if a blood meal is not taken some oocytes still develop fully.
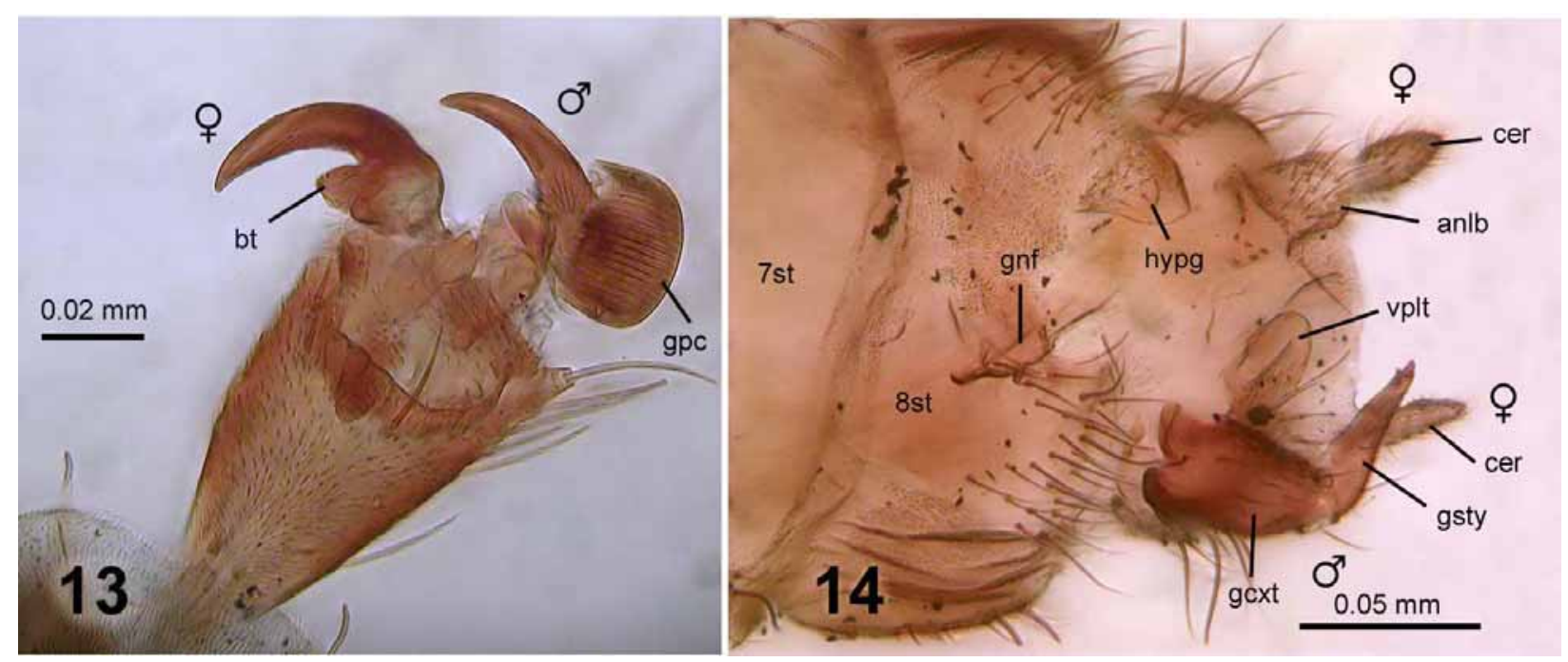

PLATE 3. Austrosimulium (Austrosimulium) ungulatum gynandromorph. Continued. Fig. 13. Pretarsal claws. Note both male and female claws. (Specimen \#1). Fig. 14. Ventral view of genitalia. (Specimen \#8). A spermatheca, normally to the left, was lost during preparation. The male $\left(\sigma^{7}\right)$ and female (우) symbols indicate structures of that sex. Abbreviations: anlb—anal lobe; bt — basal thumb; cer—cercus; gpc—grappling comb; gcxt—gonocoxite; gnf—genital fork; gsty— gonostylus; hypg — hypogynial valve; vplt — ventral plate; 7st - 7th sternite; 8st — 8th sternite;

Nothing is known about the mating habits of normal adults of New Zealand Austrosimulium. This is not surprising since Adler et al. (2004) noted that a least-observed facet of simuliid behaviour is that of mating. Crosby noted in his 1973 work on a single gynandromorph of A. australense, that normal females of this species, attempting to obtain blood meals and then to escape were all mated, containing spermatozoa in their spermathecae. Copulation is known to elicit blood feeding in simuliids and other dipterans (Downes 1958, 
Wenk 1981). Even though the egg-filled A. dumbletoni gynandromorph had a spermatheca, it appears to not contain spermatozoa. While initially there appeared to be an opening on the 8th sternite, close to where the duct from the spermathecae would normally exit on a female, detailed examination showed that there was neither an opening, nor a duct to the spermathecae. For this specimen there must have been other stimuli for egg development. From whence came the nutrients to allow hundreds of eggs to undergo vitellogenesis? Had this specimen previously had a blood meal, developed eggs and then returned for another meal, even though it could not lay its eggs, having no female gonopore. Predominately male specimens, with even minimal female structures, have a mind to bite - behaviour that normal male simuliids do not exhibit and in agreement with their rarity in collections taken around hosts of the females.

One can infer that gynandromorph \#3 of A. australense having fully expressed male genitalia, but with an attached spermatophore (Fig. 11), had mated in vain elsewhere and then had approached the penguins to feed. This is an interesting specimen since Adler et al.(2004) suggested that for Simuliidae, the spermatophore might be produced by the male within the female genital chamber during copulation. The fact that a normally-shaped spermatophore is attached to a fully male abdomen suggests that the spermatophore, rather, is fully formed by the male before deployment.

Gynandromorphs, although of aberrant and prurient mien, can provide insights into the biology of Simuliidae. However, as Crosskey (1991) noted, they also emphasize our ignorance of the sexual biology in these insects.

\section{Acknowledgements}

Considerable thanks go to B. S. Heming for discussions regarding gynandromorphy and a detailed review of an earlier draft of this work.

Support for this research was, in part, provided to DAC by Discovery Grant 5753, Natural Sciences and Engineering Research Council of Canada, and to TKC, by DSIR originally and then Landcare Research, Inc., Auckland, New Zealand.

\section{References}

Adler, P.H., Currie D.C. \& Wood, D.M. (2004) The black flies (Simuliidae) of North America. Cornell University Press, New York. 941 pp.

Allison, F.R., Desser, S.S. \& Whitten, L.K. (1978) Further observations on the life cycle and vectors of the haemosporidian Leucocytozoon tawaki and its transmission to the Fiordland crested penguin. New Zealand Journal of Zoology, 5, 371-374.

Batson, B.S. (1983) A light and electron microscopic study of Hirsutusporos austrosimulii Gen. N., Sp. N., (Microspora : Nosematidae), a parasite of Austrosimulium sp. (Diptera: Simuliidae) in New Zealand. Protistologica, 19, 263-280.

Craig, D.A. \& Craig, R.E.G. (1986) Simuliidae (Diptera: Culicomorpha) of Rarotonga, Cook Islands, South Pacific. New Zealand Journal of Zoology, 13, 357-366.

Crosby, T.K. (1973) A gynandromorph of Austrosimulium (Austrosimulium) australense (Schiner) from New Zealand (Diptera: Simuliidae). Journal of Natural History, 7, 629-631.

Crosby, T.K. (1974) Life history stages and taxonomy of Austrosimulium (Austrosimulium) tillyardianum (Diptera: Simuliidae). New Zealand Journal of Zoology, 1, 5-28.

Crosby, T.K. (1976) Austrosimulium (Austrosimulium) dumbletoni n. sp. from New Zealand (Diptera: Simuliidae). New Zealand Journal of Zoology, 3,17-19.

Crosby, T.K. (1988) Activity of three Austrosimulium species in South Westland (Diptera: Simuliidae). Proceedings of the New Zealand Society for Parasitology, 15, 331

Crosskey, R.W. (1990) The natural history of blackflies. Wiley \& Sons, Toronto. 711 pp.

Davies, L. (1965) On spermatophores in Simuliidae (Diptera). Proceedings of the Royal Entomological Society of London (A), 40, 30-34 
Desser, S.S. \& Allison, F. (1979) Aspects of the sporogonic development of Leucocytozoon tawaki of the Fiordland Crested Penguin in its primary vector Austrosimulium ungulatum: an ultrastructural study. Journal of Parasitology, 65, 737-744.

Downes, J.A. (1958) The feeding habits of biting flies and their significance in classification. Annual Review of Entomology, 3, 249-266.

Dumbleton, L.J. (1973) The genus Austrosimulium Tonnoir (Diptera: Simuliidae) with particular reference to the New Zealand fauna. New Zealand Journal of Science, 15, 480-584. (1972).

Fallis, A.M., Bisset, S.A. \& Allison, F.R. (1976) Leucocytozoon tawaki n. sp. (Eucoccida: Leucocytozoidae) from the penguin Eudyptes pachyrhynchus, and preliminary observations on its development in Austrosimulium spp. (Diptera: Simuliidae). New Zealand Journal of Zoology, 3, 11-16.

Fredeen, F.J.H. (1970) Sexual mosaics in the black fly Simulium arcticum (Diptera: Simuliidae). Canadian Entomologist, 102, 1585-1592.

Heming, B.S. (2003) Insect development and evolution. Cornel University Press. New York. 444 pp.

Hunter, D.M. \& Moorehouse, D.E. (1976) Sexual mosaics and mermithid parasitism in Austrosimulium bancrofti (Tayl.) (Diptera, Simuliidae). Bulletin of Entomological Research, 65, 549-553.

Poinar, Jr, G.O. (1990) Austromermis n. gen. and Blepharimermis n. gen. (Mermithidae: Nematoda) from New Zealand Simuliidae and Blephariceridae (Diptera). Revue de Nématologie, 13, 395-402.

Puri, I.M. (1933) A case of gynandromorphism in Simulium. Indian Journal of Medical Research, 20, 801-802.

Smart, J. (1945) The classification of Simuliidae (Diptera). Transactions of the Royal Entomological Society of London, 95, 463-528.

Sublette, J.E. \& Martin, J. (1995) Morphological variation in secondary sexual characteristics of gynandromorphic Chironomus (Camptochironomus) tentans Fabricus (Diptera, Chironomidae). In Chironomids: from genes to ecosystems (ed. P. S. Cranston), pp 343-354. Proceedings of the 12th International Symposium on Chironomidae. CSIRO, Melbourne.

Tonnoir, A.L. (1925) Australasian Simuliidae. Bulletin of Entomological Research, 15, 213-255.

Warham, J. (1974) The Fiordland Crested penguin Eudytes pachyrhychus. The Ibis, 116, 1-26.

Wenk, P. (1981) Bionomics of adult blackflies. pp 259-279. In Laird, M. (Editor) Blackflies: the future for biological methods in integrated control. Academic Press, London. 